\title{
Lexikai kohéziós eszközök változása egy sajtószöveg fordítása és lektorálása során
}

\author{
Klenk Márk \\ E-mail:klenky1990@gmail.com
}

\begin{abstract}
Kivonat: A lektorálás során a lexikai kohéziós eszközök megjelenésében bekövetkezett változások vizsgálatával kapcsolatban igen kevés kutatás született ezidáig. Jelen tanulmány a lexikai kohéziós eszközök számában bekövetkezett változást mutatja be a magyar nyelvről angol nyelvre történő fordítás és lektorálás során egy politikai témájú újságcikk példáján keresztül. A lexikai kohéziós eszközök elemzésének hátteréül Halliday és Hasan (Halliday és Hasan 1976; Hasan 1984) elmélete szolgált. Az eredmények szerint lektorálás során, a fordításhoz képest, nagymértékben megváltozott az ismétlések és szinonimák aránya, a vizsgált korpusz ezért nem igazolja Baker (1993) ismétléskerülési hipotézisét. A lektori és fordítói stratégiákat megvizsgálva megállapítható, hogy a fordítót inkább jellemzi az implicitáció, valamint a mondatfelbontás stratégiája, ezzel szemben a lektor többet explicitál, és törekszik visszaadni az eredeti mondatstruktúrákat. A kutatás eredményei jól példázzák a lektor fordítótól eltérő stratégiáját.
\end{abstract}

Kulcsszavak: lexikai kohézió, lektorálás, fordítás, lexikai ismétlés, lektori stratégia

\section{Bevezetés}

Kvalitatív, feltáró jellegü kutatásom célja egy magyarról angolra fordított politikai témájú cikkben a lexikai kohéziós eszközök változásában bekövetkező eltolódások vizsgálata volt. Ennek során három korpuszt hasonlítottam össze, egy forrásnyelvi szöveget, valamint ennek fordított és lektorált változatát. Napjainkban nagy érdeklődés övezi a hírszövegek és politikai szövegek fordításának különböző aspektusú vizsgálatait (Sárosi-Márdirosz 2014, Bánhegyi 2014, Al Majali 2015, Al-Kharabsheh és Hamadeh 2017, Károly 2017), a magyar nyelv viszonylatában azonban kevés kutatás születik. A lektorálás folyamán keletkező lexikai eltolódások elemzése szűk szakirodalommal rendelkezik, pedig ezen lexikai eltolódások vizsgálata a lektori kompetenciára és stratégiára nézve

Hivatkozás: Klenk M. 2019. Lexikai kohéziós eszközök változása egy sajtószöveg fordítása és lektorálása során. Forditástudomány 21. évf. 2. szám. 32-45.

DOI: https://doi.org/10.35924/fordtud.21.2.3 
fontos adatokkal szolgálhat. Mivel a lektor és fordító stratégiájának eltéréseire szeretnék választ kapni, jelen tanulmányban három jelenség vizsgálatára fókuszálok. Először megvizsgáltam azt, hogy a lexikai kohéziós eszközök eloszlása - a forrásnyelvi szöveghez viszonyítva - milyen mértékben változik meg a fordítás folyamata során. Ezután, a lektorált szöveg bevonásával bővítve vizsgálatomat, felmértem, hogy a lektori javítások és beavatkozások milyen mértékben okoznak változásokat ezen kohéziós elemek számában, valamint alátámasztják-e Baker (1993) ismétléskerülési hipotézisét. Végül megvizsgáltam, hogy a változások eloszlásának vizsgálatából következtethetünk-e arra, hogy a fordító és a lektor mennyiben alkalmazott eltérő stratégiát munkája során. Bár e kis korpuszon végzett elemzés alapján általánosítható megállapításokra nem juthatunk, de eredménye hipotézisállításra alkalmas a lektori illetve a fordítói stratégiával kapcsolatban.

Tanulmányom második részében bemutatom a lexikai kohézió kérdéskörével kapcsolatos eddigi kutatásokat, az elemzésem alapjául szolgáló Halliday és Hasan által kialakított taxonómiát és elemzési rendszert, valamint annak 1984ben Hasan által korszerűsített, és az addigi kutatások alapján több ponton átdolgozott változatát. Ezt követően röviden áttekintem a politikai cikkek műfajára jellemző sajátosságokat, valamit a lektorálással kapcsolatos szakirodalmat. A harmadik részben foglalkozom a kutatás módszereinek felvázolásával, a korpusz bemutatásával, az elemzés menetének bemutatásával, végül a negyedik fejezetben ismertetem kutatásom eredményeit.

\section{Elméleti háttér}

Egy fordítás csak akkor fog megfelelni a célnyelv normáinak, ha a fordító tisztában van ezekkel a normákkal. A fordított szövegek elemzésével kapcsolatos kutatások azt mutatják, hogy a fordítás eredményeképpen keletkezett szövegek mások, mint az autentikus célnyelvi szövegek. Ez a másság leginkább szövegszinten mutatkozik meg (Klaudy 2007: 145).

\subsection{A kohézió}

A kohéziókutatás célja a szöveg felszínén szövegszervező és szövegösszetartó funkciót betöltő nyelvi elemek vizsgálata. A kulturális és nyelvi rendszerbeli eltérések okán minden nyelv eltérő eszköztárral, más-más mennyiségü és minőségű eszköz segítségével fejezi ki a kohéziós viszonyokat (Károly 2007: 62).

Enkvist meghatározásában a kohézió „,a szöveg felszínén található explicit (grammatikailag leírható) kapcsolóelemeket magában foglaló terminus" (Enkvist 1990: 14; ford.: Károly 2010: 322), míg de Beaugrande és Dressler (2000) a kohéziót a szövegszerúség ismérveként tárgyalja. Megfogalmazásukban a kohézió azt fejezi ki, hogy „a szövegfelszín részei, vagyis maguk a hallott vagy látott szavak között milyen kölcsönös összefüggések vannak egy adott szósorozaton" (de Beaugrande és Dressler 2000: 24). Halliday és Hasan szerint akkor beszélünk kohézióról, ha egyes elemek megértéséhez a megnyilatkozás 
más elemeire is szükségünk van. Elméletük szerint a szövegszerüség ismérve a szövegen belül úgynevezett kötések (tie) megléte. Kiemelik, hogy a szövegszerüségnek a kohézió szükséges, de nem egyedüli feltétele (a necessary though not a sufficient condition), mivel szöveget a nyelvi rendszer különböző szövegalkotó elemei hoznak létre, ennek a kohézió csupán egy részét képezi (Halliday és Hasan 1976: 298-299). Ők a referenciát, helyettesítést, ellipszist, konjunkciót és a lexikai kohéziót mint különálló kohéziótípusokat különítették el egymástól. A kohéziót a szövegen belüli jelentések kapcsolataiként, a szövegszerűség ismérveként definiálják. A szöveget egységes egésznek tekintik, a nyelvhasználat egységének, szemantikai egységnek. A kohézió nem mondatokat kapcsol össze, hanem a „szöveg egy elemének szemantikai viszonya egy másikhoz, amely elem az elsőnek az értelmezéséhez szükséges" (Halliday és Hasan 1976: 8; idézi Tolcsvai 2001: 25). A kohézió nemcsak a mondatok között, hanem a mondaton belül is jelen van, azonban ez kevesebb figyelmet érdemel, mivel a mondatszint alatt a grammatikai struktúra fejt ki magasabb szintű összetartó erőt.

Kohéziós eltolódáson azt a jelenséget értjük, amelynek során egy, a forrásnyelvi szövegben jelen lévő kohéziós eszközt a fordító egy másik eszközzel helyettesít, vagy kihagy. A fordítástudományon belül a kohéziós vizsgálatok célja elsősorban ezeknek a kohéziós eltolódásoknak a feltérképezése egyes nyelvpárok esetében (Károly 2012: 304). Blum-Kulka kötelező és választható kohéziós kötéseket különböztet meg egymástól. A kötelező kohéziós kötések a grammatikai rendszerek közötti eltérésekből adódnak, míg a választható kohéziós kötések a célnyelvi szövegalkotási, múfaji és stilisztikai sajátosságokon alapulnak (Blum-Kulka 1986: 304). Véleménye szerint - éppen ezért - csak az opcionális kohéziós kötésekben bekövetkező változásokat kell figyelembe venni, mivel ezek utalhatnak bizonyos tendenciákra a fordítás során bekövetkező kohéziós eltolódással kapcsolatban. Tanulmányában három lehetséges eredményt különböztet meg a kohéziós mintázat változásában a két nyelv között:

1. A kohéziós eszközök célnyelvi mintázata megközelítően azonos az azonos regiszterbe tartozó eredeti célnyelvi szövegek kohéziós mintázatával.

2. A célnyelvi szöveg kohéziós mintázata az azonos regiszterbe tartozó forrásnyelvi szövegalkotási normákat tükrözi.

3. A célnyelvi szöveg kohéziós mintázata mind a célnyelvi, mind a forrásnyelvi normáktól eltér, egy sajátos rendszert formál, az explicitáció folyamatát jelzi.

Jelen tanulmány a lexikai kohéziós eszközök vizsgálatával foglalkozik, így a következő alfejezetben ezek kutatásával kapcsolatos eredményekre térek ki.

\subsection{A lexikai kohéziós eszközök eddigi kutatásainak eredményei}

A grammatikai elemek által teremtett kohézióval szemben a lexikai kohéziót a szöveg lexikai egységei közötti relációk hozzák létre (Károly 2007: 96). Tanulmányomban az elemzés hátteréül Halliday és Hasan (Halliday és Hasan 
1976; Hasan 1984) műve szolgál, akik a lexikai kohéziót olyan kohéziós hatásként tárgyalják, mely a lexikai szavakból való választás eredményeként jön létre. Az 1976-os taxonómiában a lexikai kohézió két alfajtájaként az ismétlést, valamint a kollokációt különítették el egymástól. Az ismétlés fogalmát tágan, egy skálán értelmezték, amelynek egyik végén a szó szerinti ismétlés található, a másik végén pedig azon elemek, amelyek általános értelemben utalnak viszsza egy korábbi lexikai elemre. Ezen skála két végpontja között helyezkedik el a szinonima, a közel szinonima, valamint a fölérendelt viszonyok (Halliday és Hasan 1976: 276-278). Már ők is hangsúlyozzák, hogy a lexikai kohézió legproblematikusabb része a kollokációk kérdése. A kollokációk kohéziós erejét nem egy közöttük fennálló szisztematikus szemantikai kapcsolatból származtatják, hanem abból, hogy ezek az elemek általában együtt fordulnak elő a szövegben. Ugyanezt Károly is kiemeli, „ez talán modelljük legproblematikusabb része, mert sok esetben intuíción alapul a megítélés" (Károly 2007: 70). A lexikai kohézió leírására általuk javasolt keretrendszert az 1. táblázat szemlélteti.

1. táblázat

Lexikai kohéziós eszközök (Halliday és Hasan 1976: 288 alapján)

\begin{tabular}{|l|l|}
\hline \multicolumn{1}{|c|}{ Lexikai kohézió típusa } & \multicolumn{1}{|c|}{ Referenciális kapcsolat } \\
\hline 1. Ismétlés & \\
\hline a) szó szerinti ismétlés & ugyanaz a referens \\
\hline b) szinonima (vagy közel szinonima) & inkluzív referenciális kapcsolat \\
\hline c) fölérendelt viszonyok & exkluzív referenciális kapcsolat \\
\hline d) általános szó & nincs kapcsolat \\
\hline 2. Kollokáció & \\
\hline
\end{tabular}

Halliday és Hasan (1976) a kohéziós modell ismertetése mellett leírta és illusztrálta is a modell alkalmazásának módját. Az azonban egyes esetekben nehezen volt elhatárolható, hogy az adott lexikai egység milyen kötési kategóriába tartozik, mivel nem szolgáltak pontos definíciókkal egyik kategóriára nézve sem. Hasan 1984-es tanulmányában meghatározta a kohézív harmónia fogalmát és párhuzamba állította azt a koherenciával. Kifejtette, hogy a kohéziós eszközök láncokat alkotnak és ezeken a láncokon belül is előfordulhatnak még további relációk, amelyek a koherenciát erősítik. Abban az esetben tart koherensnek egy szöveget, ha annak elemei összetartoznak a köztük lévő szemantikai kapcsolatok eredményeképpen.

Hasan (1984: 201) megkülönbözteti egymástól az általános szemantikai relációkat és a pillanatnyi, vagyis szövegalapú relációkat. Az általános szemantikai relációk kategóriáját öt csoportra osztja, melyek az alábbiak: ismétlés, szinonima, antonima, hiponímia és meronímia. Ezek a relációtípusok általános érvényüek, túlmutatnak a szöveg keretein. Ezzel szemben a pillanatnyi relációk 
szövegfüggő relációnak tekinthetők, a két elem között nincs általános érvényü szemantikai kapcsolat, az az adott szövegkörnyezet függvényében alakul ki. Ezek alapján, az elemzésem alapjául szolgáló lexikai kohéziós elemzési keretrendszert a 2. táblázat szemlélteti. A táblázatban szereplő példák a forrásszöveg, valamint a lektorált szöveg elemzéséből származnak.

\section{2. táblázat}

\section{Lexikai kohéziós eszközök kategóriái (Hasan 1984 alapján)}

\begin{tabular}{|c|c|c|}
\hline & \multicolumn{2}{|c|}{ Általános szemantikai relációk } \\
\hline & magyar & angol \\
\hline 1. ismétlés & migráns, választás & migrant, election \\
\hline 2. szinonima & kerítés $\sim$ határ & fence $\sim$ border \\
\hline 3. antonima & ellenzéki pártok Fidesz-KDNP & $\begin{array}{l}\text { opposition parties } \sim \text { governing } \\
\text { parties }\end{array}$ \\
\hline 4. hiponímia & határ $\sim$ kerítés & border $\sim$ fence \\
\hline \multirow[t]{2}{*}{ 5. meronímia } & választás szavazat & election $\sim$ polling station \\
\hline & \multicolumn{2}{|c|}{ Pillanatnyi (szövegalapú) relációk } \\
\hline 1. azonosság & $\begin{array}{l}\text { „.. - mondta Orbán Viktor } \\
\text { miniszterelnök...” } \\
\text { „„... - hangsúlyozta a pártelnök- } \\
\text { kormányfo"” }\end{array}$ & $\begin{array}{l}\text { “... Prime Minister Viktor Orbán } \\
\text { said that...” } \\
\text { “...the Prime Minister and party } \\
\text { president said..." }\end{array}$ \\
\hline 2. elnevezés & $\begin{array}{l}\text { „Egy hazánk van, nincs másik.” } \\
\text { 〜 „Mindenkinek aki meg akarja } \\
\text { őrizni Magyarországot magyar } \\
\text { országnak, ...” }\end{array}$ & $\begin{array}{l}\text { "We only have a single country, } \\
\text { we have no other." "Everyone } \\
\text { who wants to preserve Hungary as } \\
\text { a Hungarian country..." }\end{array}$ \\
\hline 3. hasonlat & $\begin{array}{l}\text { vasárnapi sorsdöntő ütközet } \\
\text { választás }\end{array}$ & fateful battle on Sunday election \\
\hline
\end{tabular}

Halliday és Hasan munkájára építve számos egyéb elemzési rendszert is kialakítottak. A kohéziós eszközök vizsgálatai közül a legnagyobb figyelmet a lexikai ismétlődések szövegalkotó szerepe kapta. A leggyakrabban idézett forrásnak Hoey 1991-es Pattern of Lexis in Text címü munkája tekinthető, amely a lexikai ismétlés szövegszervező, szövegalkotó munkájáról szól. Hoey abból a felvetésből indult ki, hogy a kohézió inkább lexikai mintsem grammatikai relációk eredményeként jön létre. A lexikai relációkat az ismétlődés különböző szintjeinek tartja, melyek a szövegben összetartozó, egymásra vonatkozó mondatok struktúráját adják meg. Hoey elemzésével különbséget tudunk tenni a szövegben centrális (kulcsfontosságú) és marginális (mellékes) mondatok között. Modellje szerint ezek a centrális mondatok közvetítik a szöveg tartalmát, mivel ezen mondatok között található a legtöbb kapcsolat (Károly 2007: 74-76). 


\subsection{Ismétlés mint lexikai kohéziós eszköz}

A lexikai kohéziós eszközök vizsgálata kapcsán fontos említést tenni még az ismétlések szövegalkotó funkciójáról is. Ahogy Károly is kiemeli: „Bár az ismétlés megítélése ellentmondásos, a lexikai ismétlésnek mint kohéziós eszköznek fontos szövegszerkesztő funkciója van.” (Károly 2011: 11). Míg például a magyar és svéd nyelvben a gyakori szóismétlést általában negatívan értékelik, addig az arab és görög nyelv esetén ez elfogadottnak tekinthető. Baker szerint az ismétlések kerülése univerzális fordítói eljárásnak tekinthető, mivel „az ismétléseket a fordítók vagy kihagyják vagy szinonimákkal váltják fel" (Baker 1993, idézi Klaudy 2007:186). Faludi tanulmányában előzetes feltételezésként emelte ki, hogy ez a jelenség nagy valószínűséggel müfajfüggő, vagy legalábbis léteznek olyan speciális korpuszok, amelyekben ennek ellentéte, az ismétlődésekre való törekvés a jellemző (Faludi 2015). Ezt az állítást alátámaszthatják a szakszövegek körében végzett vizsgálatok. Az egyes szaknyelvek meghatározott terminológiával rendelkeznek, melyek körében alacsonynak tekinthető a szinonimitás. Ha a mondandó pontos és megfelelő átadása a cél, a megértési nehézségek elkerülése érdekében, mind forrásnyelven, mind célnyelven a fordításban, elkerülhetetlen a meghatározott terminológiai egységek ismétlése.

\subsection{Múfaji sajátosságok}

Az elemzésem tárgyául választott szöveg egy politikai témájú hírszöveg, így az alábbiakban ezen múfajra vonatkozó legfontosabb kutatási eredményeket tekintem át. A politikai szövegek kategóriája igen tágan értelmezhető. Chilton és Schäffner (1997) a politikai szövegeket funkciójuk szerint négy kategóriába sorolja. Az első kategóriába a korlátozó, kényszerítő funkcióval rendelkező szövegek tartoznak. Többek között ide sorolják a kérdésekre adott rögtönzött válaszokat, a napirendi pontok meghatározásait, valamint mások nyelvhasználatának korlátozását is (pl. cenzúra). A második kategóriába az ellenállást, szembenállást és tiltakozást kifejező szövegek tartoznak, mint például a graffiti, szlogenek vagy petíciók. A harmadik kategóriába tartozó szövegek funkciója a palástolás, mely stratégia megnyilvánulhat mind az információ korlátozásában, mind az információt közlő szövegek ellenőrzésében. Végül az utolsó kategóriába a legitimizációs és delegitimizációs funkcióval rendelkező szövegek tartoznak. Ide sorolhatjuk azokat a szövegeket, amelyeknek célja a szavazók akaratának bemutatásával, (politikai) szereplők teljesítményének dicséretével, valamint delegitimizáció esetén negatív fényben való feltüntetésével (Károly 2007: 169-170). Az elemzésem tárgyául választott szöveg ebbe az utolsó kategóriába tartozik.

A hírszövegek leírásának elméletével kapcsolatban Bell (1991; 1998) munkái tekinthetők legmeghatározóbbnak a nemzetközi szakirodalomban. Elmélete szerint a hírszövegek három alapelemből állnak: (a) tulajdonítás (hírügynökség, szerző), (b) absztrakt (föcím, alcím/összefoglalás) és (c) történet (epizódok és események sora), és ezek további elemekkel bővülhetnek (pl. háttér, kommentár, utóesemények) (Károly és Ábrányi et al. 2012: 40). A Bell (1998) által ki- 
dolgozott eseménystruktúra-modell segítségével leírható az újságcikkek tartalmi szerkezete, valamint a szövegben megjelenő információk segítségével rekonstruálható az, hogy mi történt a valóságban. A müfajra jellemző sajátosságnak tekinthető a kifejező címadás stratégiája. Tolcsvai a címet a szöveggel kapcsolatos kategóriák közül az egyik legösszetettebbnek tekinti, a címnek kettős funkciót tulajdonít. Az egyik a szövegre mint egészre utaló metatextuális funkció, a másik pedig a tartalmi funkció, amely a szövegre mint tartalmas értelmi egységre utal (Tolcsvai 2001: 325-331). A címek a szövegek kulcsszereplöi, ezért mind fordítási, mind szövegtani szempontból érdekes kérdéseket vethetnek fel. Nyelvi, müfaji és kulturális szempontból eltérő variációkat mutatnak, valamit egyedülálló szereppel rendelkeznek a szövegkoherencia megteremtésében is (Károly 2007: 208).

\subsection{Lektorálás}

Kis és Mohácsi-Gorove (2008: 367) A forditó számitógépe címü könyvének szószedetében a lektorálás „a célnyelvi szöveg ekvivalenciájának, egységességének és helyességének ellenőrzése, illetve javítása" meghatározással szerepel. Horváth (2011) disszertációja a lektorálás témakörében öt hipotézis köré szerveződik. Úgy véli, hogy a lektorálás egy sajátos tevékenységnek tekinthető, több szempontból is eltér a fordítástól, ezért a hátterében mindenképpen léteznie kell valamilyen ismeretnek vagy képességnek, amelyek ezt lehetővé teszik. Ezen ismeretek és képességek halmazát lektori kompetenciának nevezi. A gyakorlat azt mutatja, hogy a lektorok a rövid határidők ellenére is több változást hajtanak végre a fordított szövegeken, mint az a megrendelő számára szükséges lenne. Kiemeli, hogy kevés az olyan lektori változtatás, amely egész tagmondatokat vagy egész mondatokat érintene, ha valami megváltozik a fordításban, az legnagyobbrészt a szavak és kifejezések szintjén valósul meg. Hangsúlyozza, hogy a lektor feladata a fordító által teremtett ekvivalencia szintjének ellenőrzése, vagyis annak biztosítása, hogy a fordítás ugyanazt a szerepet töltse be a célnyelvben, mint amit a forrásnyelven is betöltött. Véleménye szerint, a fordításhoz hasonlóan, a lektorálásban is megfigyelhetünk univerzális jelenségeket (Horváth 2011: 22-23). A lektor a lektorálás folyamán azt vizsgálja, hogy a célnyelvi szöveg - az előzetes elvárások alapján - megfelel-e a forrásszövegnek. Fentről lefelé halad, a szöveget makroszinten szemléli, a kész szöveg egészéhez viszonyítja az egyes mondatok nyelvi és tartalmi megfeleléseit, valamint kölcsönös összefüggéseit. Összegezve elmondhatjuk, hogy a lektorálás során a lektor kiindulópontja a célnyelvi szöveg, célja a szöveg értékelése, az ekvivalencia ellenőrzése. Stratégiája globális, a szöveget makroszinten vizsgálja, munkáját jellemzi a saját szemlélet valamint nyelvhasználat erőltetése (Horváth: 2011: 34-36). Ennek némileg ellentmondanak Robin (2014) kutatásai, aki kiemeli hogy a szószintű kihagyások és betoldások mellett ugyanakkor jellegzetes lektori múveletnek számítanak a mondatszintű beavatkozások is. 


\section{A kutatás módszertana}

\subsection{A korpusz}

A korpusz egy, a www.kormany.hu weboldalon megjelent politikai témájú cikkből, valamint annak fordított és lektorált változatából áll. Olyan szöveget szerettem volna választani, amelyben a lektor nagy mennyiségú változtatást hajtott végre, mivel ezek a változtatások majd jól fogják szemléltetni a fordítói és lektori stratégiában megjelenő esetleges hasonlóságokat, illetve eltéréseket (lásd 4.1 fejezet). A honlap mindenki számára elérhető, a magyar kormány hivatalos információs honlapja, amely folyamatosan frissülve aktuális híreket, beszámolókat és multimédiás tartalmakat közöl a kormány munkájával kapcsolatban. Az angol nyelvü honlap további célja a külföldi sajtóorgánumok tájékoztatása. A korpusz három részből áll. A magyar forrásnyelvi szöveg (a továbbiakban: FNY) összesen 732 szó, a fordított angol nyelvü szöveg (a továbbiakban CNY) 1029 szó, továbbá a lektorált angol nyelvű szöveg (a továbbiakban: CNYLE) szószáma 1072 szó. A cikk témája a választás előtti kormányzati kommunikációval kapcsolatos, címe Sorsdöntö választás követke$z i k$, és jó példaként szolgál a Chilton és Schäffner (1997) által definiált legitimizációs funkciójú szövegek kategóriájára. A magyar nyelvủ cikk a választások előtt három nappal került publikálásra, a lektorált szöveg pedig a választások előtti napon.

\subsection{Az elemzés módszertana}

Az elemzés során először tagoltam a forrásnyelvi, valamint a célnyelvi szövegeket, minden mondatot sorszámmal láttam el a későbbi könnyebb azonosíthatóság érdekében. A címet minden esetben az 1-es sorszámmal láttam el. Ezután a 2.2 fejezetben ismertetett Hasan által kidolgozott taxonómia és lexikai kohéziós elemzési módszer alapján mindhárom szövegben megvizsgáltam a lexikai kohéziós eszközöket és összevetettem a magyar nyelvű eredeti szöveget az angol fordított és lektorált változattal. Elemzésem során nemcsak az egyszavas lexikai elemeket vizsgáltam, hanem Károly et al. (2012) alapján, a „lexikai egység” meghatározását alapul véve (vagyis lexikai egységnek tekinthetünk minden olyan egységet, melynek jelentése nem vezethető le egyes alkotóelemeik jelentéséből) a szorosan összetartozó szavak csoportjait is egy egységként kezeltem. Így például a FNY-ben előforduló kampányzáró rendezvény és a CNY-ben megjelenő campaign closing event, valamint az FNY-ben előforduló kötelezö betelepitési kvóta és a CNYLE-ben előforduló mandatory migrant resettlement quota is egy egységként szerepel a vizsgálatban. Az adatok összegzése után megvizsgáltam a kötéstípusok eloszlásában és gyakoriságában felmerülő különbségeket és feltártam azoknak lehetséges okait. A három korpusz kis méretére való tekintettel statisztikai elemzésre és ellenőrzésre nem volt lehetőség. 


\subsection{Mintaelemzés}

A következőkben három mintán bemutatva szemléltetem az elemzés menetét. Az előző pontban leírtak szerint a szöveget először mondatokra tagoltam és a mondatokat sorszámmal láttam el. A cím minden esetben az 1 . sorszámot kapta. Mintaelemzésemben (3. táblázat) aláhúzással jelöltem a kohéziós eszközöket, a kötés típusát pedig zárójelben, alsó indexben a szövegbe illesztettem.

\section{3. táblázat}

\section{Mintaelemzés}

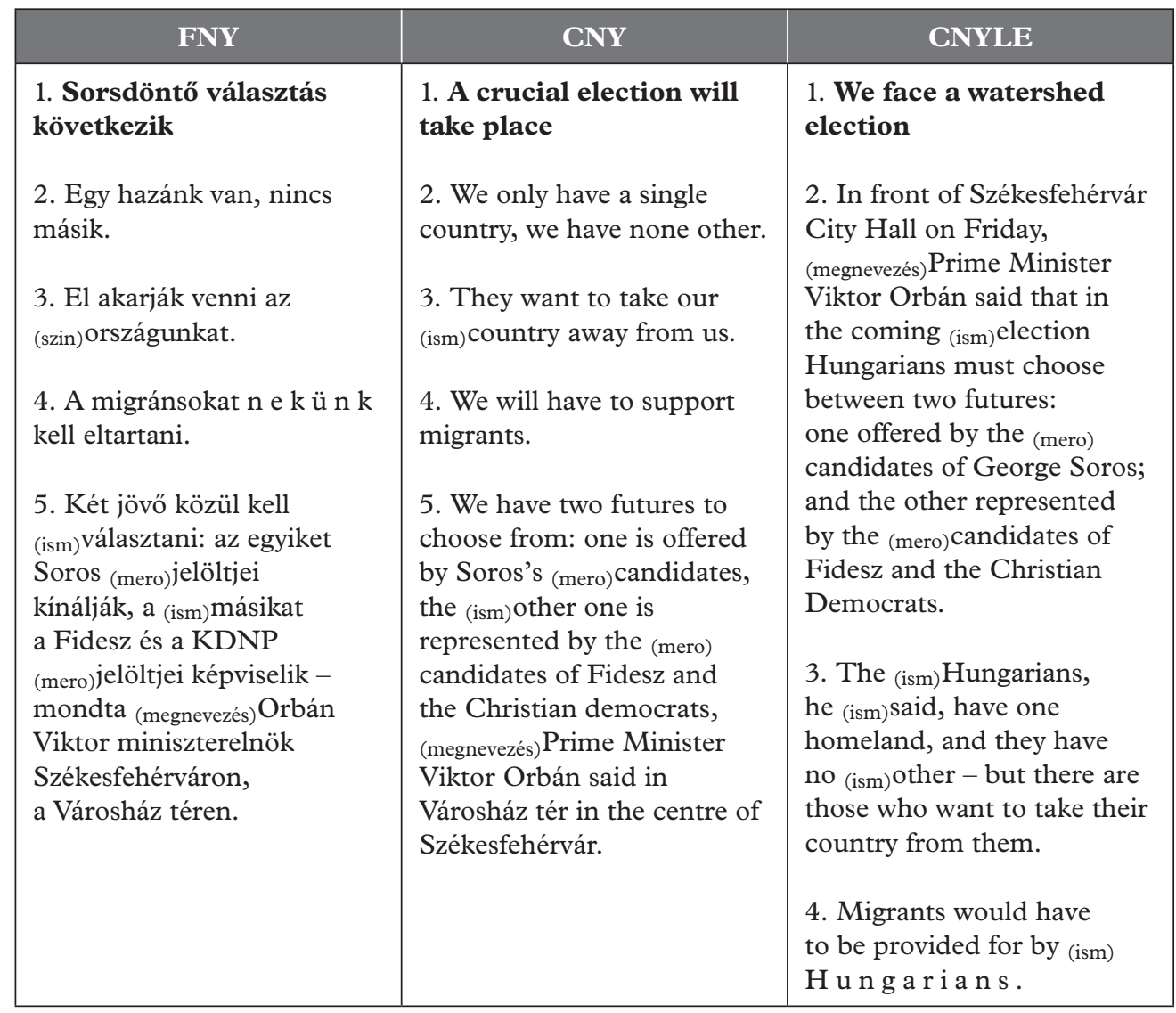




\section{Eredmények}

A lexikai kohéziós eszközök kvantitatív elemzésének eredményeit és az egyes szövegekben megjelenő kohéziós eszközök számát a 4. táblázat mutatja be részletesen.

\section{4. táblázat}

A kohéziós eszközök gyakorisága a magyar forrásnyelvi, az angol célnyelvi valamint az angol lektorált korpuszokban

\begin{tabular}{|c|c|c|c|}
\hline \multirow{2}{*}{$\begin{array}{c}\text { Lexikai kohéziós eszköz } \\
\text { elnevezése }\end{array}$} & FNY & CNY & CNYLE \\
\cline { 2 - 4 } & 91 & 90 & 108 \\
\hline ismétlés & 34 & 29 & 16 \\
\hline szinonima & 4 & 3 & 2 \\
\hline antonima & 2 & 1 & 1 \\
\hline hiponímia & 5 & 6 & 5 \\
\hline meronímia & 17 & 15 & $\mathbf{1 4 8}$ \\
\hline pillanatnyi relációk & $\mathbf{1 5 3}$ & $\mathbf{1 4 4}$ & \\
\hline Összesen & & &
\end{tabular}

A lexikai kohéziós eszközök darabszámát tekintve elhanyagolható a különbség az FNY és CNY szövegek között, azonban a FNY és CNYLE szövegek között már számottevőnek mondható. Ez az eltérés leginkább az ismétlések számának növekedésében és a szinonimák számának csökkenésében mutatkozik meg. Jelen elemzés során kapott adatok így sem a fordító, sem a lektor stratégiájára vonatkoztatva nem igazolják Baker (1993) ismétléskerülési hipotézisét, mely szerint a fordítók a célnyelvi szövegalkotás során a lexikai elemek ismétlése helyett inkább a kihagyás vagy a szinonima használatának módszerét választják.

Több esetben megfigyelhető az, hogy a lektor lexikai ismétlést told be a szövegbe olyan helyeken, ahol eredetileg nem az szerepelt. Ezt jól szemlélteti a mintaszövegben ritkított betűvel közölt (FNY 4, mondat, CNY: 4. mondat, CNYLE 4. mondat) példa is. Míg a magyar eredetiben és a fordításban is grammatikai eszköz fejezte ki a kohéziós viszonyt (nekünk, we), addig a lektorálás során ezt a grammatikai kohéziós eszközt a lektor lexikai ismétlésre cserélte (Hungarians). Ugyanígy, a szinonimák számának csökkenését okozhatta azok ismétlésre cserélése a lektorálás során. A szöveg jellegét tekintve számos szóbeliségre történő utalás található benne (mondta, emelte ki, hangsúlyozta, közölte stb.), melyeket elemzésem során szinonimáknak tekintettem. Az 5. táblázat ezen szóismétlések alkalmazását szemlélteti a szövegben az eredetileg szinonima (vagy más kategóriájú elem) használata helyett. 


\section{5. táblázat}

Szóbeliségre történö utalások alakulása a fordított és lektorált szövegben

\begin{tabular}{|c|c|c|}
\hline FNY & CNY & CNYLE \\
\hline $\begin{array}{l}\text { 5. „...- mondta Orbán } \\
\text { Viktor miniszterelnök...” }\end{array}$ & $\begin{array}{l}\text { 5. “... Prime Minister Viktor } \\
\text { Orbán said in ..." }\end{array}$ & $\begin{array}{l}\text { 1. “... Prime Minister Viktor } \\
\text { Orbán said that...” }\end{array}$ \\
\hline $\begin{array}{l}\text { 11. „... a kommunista rend- } \\
\text { szer végén álltunk ilyen válasz- } \\
\text { útnál”- (szin)hangsúlyozta.” }\end{array}$ & $\begin{array}{l}15 . \text { "... at the end of the } \\
\text { communist regime", he (szin) } \\
\text { stressed." }\end{array}$ & $\begin{array}{l}\text { 12. "at the end of the } \\
\text { communist system, he (ism) } \\
\text { said." }\end{array}$ \\
\hline $\begin{array}{l}\text { 15. „Hiába szeretné, még } \\
\text { a német kancellárnak sem } \\
\text { áll hatalmában a történelem } \\
\text { kerekét visszafelé forgatni - } \\
\text { fogalmazott a kormányfo"." }\end{array}$ & $\begin{array}{l}\text { 18. "Much as she would } \\
\text { like, not even the German } \\
\text { chancellor has the power } \\
\text { to turn back the wheel of } \\
\text { history, the Prime Minister } \\
\text { said." }\end{array}$ & $\begin{array}{l}\text { 15. "... the Prime Minister } \\
\text { said, adding that whether or } \\
\text { not she would like to, even } \\
\text { the German chancellor does } \\
\text { not have the power to turn } \\
\text { back the wheels of history." }\end{array}$ \\
\hline
\end{tabular}

Összefoglalva elmondható, hogy a korpuszban nem igazolható az ismétléskerülési hipotézis. A lektorált CNYLE szövegben nagymértékben megnövekedett az ismétlések száma, míg a FNY és CNY szövegekben az ismétlések és szinonimák száma közel azonos.

\subsection{A lektori és fordítói stratégia eltérései}

A lexikai kohéziós eszközök darabszámának elemzéséből láthattuk, hogy lektorálás után a lektorált szövegben - részben a szinonimák kárára - nagymértékben megnövekedett az ismétlések száma. Ha mindhárom szövegben megvizsgáljuk a mondatok számát (eredeti: 38 mondat, fordított: 47 mondat, lektorált: 40 mondat) arra a megállapításra juthatunk, hogy a fordítás során megnövekedett mondatszámot a lektorálás folyamán a lektor az eredeti mennyiséghez közelítette. A 6. táblázat mintaszövege is ezt a lektor általi mondatösszevonási stratégiát szemlélteti. A forrásnyelvi magyar részlet három mondatból áll, ezt a fordítási folyamat során a fordító hat mondatban ültette át a célnyelvre, majd a lektor két mondatba vonta össze azt. A mintaszövegben a lektor által elvetett szövegrészeket áthúzással, a betoldott szövegrészeket pedig pirossal jelöltem. Klaudy az átváltási műveletek közül a grammatikai felbontás kategóriájába sorolja a fordító által elvégzett, egyetlen forrásnyelvi mondat több célnyelvi mondatra való bontását. Hangsúlyozza, hogy ezt az átváltási műveletet viszonylag ritkán használják a fordítók, a mondathatárok felbontását nem tekinthetjük kötelező átváltási műveletnek, rendszerint a fordító egyéni fordítási stratégiáját tükrözik (Klaudy 2012: 189-190). 


\section{6. táblázat}

\section{Mondatösszevonások lektorálás során}

\begin{tabular}{|c|c|}
\hline FNY & CNY+CNYLE \\
\hline $\begin{array}{l}\text { Orbán Viktor szerint ezért } \\
\text { mindenkinek el kell mondani, } \\
\text { hogy ,végre van jövőnk, van mit } \\
\text { megvédenünk”. A veszélyek közül } \\
\text { a legnagyobbnak a bevándorlást } \\
\text { nevezte. „Mi megépítettük } \\
\text { a kerítést, megvédtük a déli határt, } \\
\text { nemet mondtunk Brüsszelben } \\
\text { minden betelepítésre, de a veszély } \\
\text { nem múlt el, alig várják, hogy } \\
\text { újrakezdjék” - fogalmazott, jelezve: } \\
48 \text { óra van arra, hogy ezt újból } \\
\text { elmondják mindenkinek. }\end{array}$ & $\begin{array}{l}\text { According to Ar, Orbán, we the Prime Minister, one } \\
\text { must therefore tell everyone that, ,at last we finally } \\
\text { have future, and we have something to proteet”. He } \\
\text { deseribed defend”. Of the dangers that exist, he said } \\
\text { the greatest is immigration as the number of threat. } \\
\text { "We:: „we have built the border fence. We proteeted, } \\
\text { we have defended the southern border. We said no, in } \\
\text { Brussels to we have rejected every proposal for migrant } \\
\text { resettlement of any kind,; but the danger is has not } \\
\text { over yet. They ean hardly passed, and they cannot } \\
\text { wait to start begin again”, he said, indieating adding } \\
\text { that we have there is } 48 \text { hours to in which to once } \\
\text { again tell everyone about this one more time.. }\end{array}$ \\
\hline
\end{tabular}

A mondatok számának megváltoztatásán, a mondathatárok átalakításán kívül a lektori és fordítói stratégiában még egy feltűnő jelenségre figyeltem fel. Ahogy a 7. táblázatban is látszik, a lektor munkáját inkább jellemzi az explicitáció (dőlt betüs) a fordító munkájával szemben. Ezek az explicitációs javítások részben közrejátszhatnak az ismétlések számának növekedésében, mivel több esetben az eddig grammatikai kohéziós kötéseket (pl. 1. példa) változtatja a lektor lexikai kohéziós kötésekké.

\section{7. táblázat}

Példák az explicitációra a fordított és lektorált szövegben

\begin{tabular}{|c|c|c|c|}
\hline No & FNY & CNY & CNYLE \\
\hline 1 & $\begin{array}{l}\text { „El kell mondani } \\
\text { mindenkinek, hogy az első } \\
\text { tízezer bevándorlót még az } \\
\text { idén ide akarják telepiteni” }\end{array}$ & $\begin{array}{l}\text { "We must tell everyone } \\
\text { that they want to } \\
\text { resettle the first ten } \\
\text { thousand immigrants" }\end{array}$ & $\begin{array}{l}\text { "He said that everyone must } \\
\text { be told that Brussels wants to } \\
\text { resettle the first ten thousand } \\
\text { immigrants" }\end{array}$ \\
\hline 2 & $\begin{array}{l}\text { „Szerinte azonban most } \\
\text { vasárnap győzni fognak.” }\end{array}$ & $\begin{array}{l}\text { "However, in his view, } \\
\text { this Sunday they will } \\
\text { win." }\end{array}$ & $\begin{array}{l}\text { "In his view, however, this } \\
\text { Sunday the governing parties } \\
\text { will win." }\end{array}$ \\
\hline 3 & $\begin{array}{l}\text { „A miniszterelnök szerint } \\
\text { a dolgok a kampány végére } \\
\text { leegyszerüsödtek:” }\end{array}$ & $\begin{array}{l}\text { "According to the } \\
\text { Prime Minister, by the } \\
\text { end of the campaign" }\end{array}$ & $\begin{array}{l}\text { "The Prime Minister thinks } \\
\text { that in the final stages of the } \\
\text { campaign" }\end{array}$ \\
\hline 4 & $\begin{array}{l}\text { „... nemet mondtunk } \\
\text { Brüsszelben minden } \\
\text { betelepitésre..." }\end{array}$ & $\begin{array}{l}\text { “... We said no in } \\
\text { Brussels to resettlement } \\
\text { of any kind..." }\end{array}$ & $\begin{array}{l}\text { "...in Brussels we have } \\
\text { rejected every proposal for } \\
\text { migrant resettlement..." }\end{array}$ \\
\hline
\end{tabular}

Ezen eltérések a fordítási és lektorálási feladat eltérő lényegéből adódnak. Ahogy Horváth (2011) is kiemelte, a lektor feladata leginkább a fordító által 
teremtett ekvivalencia szintjének ellenőrzése, annak biztosítása, hogy a fordítás ugyanazt a szerepet töltse be a célnyelvben, mint amit a forrásnyelvben. Vagyis, a lektor mint a célnyelvi szöveg első olvasója, más szemmel tekint a szövegre mint a fordító. Célja az ekvivalencia biztosítása, a célnyelvi múfaji struktúrának, a célnyelvi olvasó elvárásainak való megfeleltetés.

\section{5. Összegzés}

Tanulmányomban egy magyarról angolra fordított, politikai témájú sajtócikk példáján keresztül mutattam be a lexikai kohéziós eszközök alakulásának változását a fordítás és lektorálás során. A lexikai kohéziós eszközök tekintetében nagy eltérés volt kimutatható a CNYLE szövegben az ismétlések számának növekedésében, valamint a szinonimák számának csökkenésében mind a FNY, mind a CNY szöveghez képest. Ez megerősíti Robin kutatásait (2014), aki diszszertációjában a lektorált szövegeket elemezve arra a megállapításra jutott, hogy

A lektor [...] az általa gondozott szöveg szókincse és redundanciája alapján dolgozik, akár az általános lektorálási tendenciával szembefordulva végzi a munkáját: ha szükséges, növeli a redundanciát, visszaszorítja az ismétléskerülést, csökkenti a szókincs változatosságát, gazdagságát, ezáltal az információs terhet is [...]. (Robin 2014: 114).

A fordítói és lektori stratégia vizsgálata során arra a megállapításra jutottam, hogy a lektori munkát inkább az explicitáció jellemezte, valamint a fordítás során szétbontott mondatstruktúrák újraegyesítése. Az eltolódások számában bekövetkezett változások inkább minőségi szempontból relevánsak, a kohéziós eszközök számában csak elhanyagolható változás volt felfedezhető, így a vizsgált korpusz alapján az ismétléskerülési hipotézis nem bizonyítható. A későbbiekben azonban érdemes lenne ugyanazon fordító-lektor párostól még több szöveg elemzésével bővíteni a korpuszt, annak érdekében, hogy akár statisztikai alapon is igazolható, releváns eredményt kapjunk, mind a kohéziós eszközök használatában bekövetkezett változással, mind a lektori és fordítói stratégia eltéréseivel kapcsolatban.

\section{Irodalom}

Al-Kharabsheh A., Hamadeh N. 2017. Shifts of Cohesion and Coherence in the Translation of Political Speeches. Advances in Language and Literary Studies Vol. 8. No. 3. 100-112.

Al Majali, W. 2015. Discourse Analysis of the Political Speeches of the Ousted Arab Presidents during the Arab Spring Revolution using Halliday and Hasan's Framework of Cohesion. Fournal of Literature, Languages and Linguistics Vol. 3. No. 10. $35-48$.

Baker, M. 1993. Corpus Linguistics and Translation Studies. Implications and Applications. In: Baker, M., Francis, G., Tognini-Bonelli, E. (eds) Text and Technology: In honour of Fohn Sinclair. Amsterdam: Benjamins. 233-250. 
Bánhegyi M. 2014. Translation and Political Discourse. Acta Universitatis Sapientiae, Philologica Vol. 5. No. 2. 139-158.

Beaugrande, R. d., Dressler W. U. 2000. Bevezetés a szövegnyelvészetbe. Budapest: Corvina.

Bell, A. 1991. The language of news media. Oxford: Blackwell.

Bell, A. 1998. The discourse structure of news stories. In: Bell, A., Garrett, P. (eds) Approaches to media discourse. Oxford: Blackwell. 64-104.

Blum-Kulka, S. 1986. Shifts of Cohesion and Coherence in Translation. In: Venuti., L. (ed) The translation studies reader. London: Routledge. 290-305.

Chilton, P., Schäffner, C. 1997. Discourse and politics. In: van Dijk, T. A. (ed.) Discourse as social interaction: discourse as social interactions. vol. 2, Discourse Studies: A Multidisciplinary Introduction. London: SAGE. 206-230.

Faludi A. 2015. Lexikai kohéziós vizsgálat CAT-tel fordított szövegeken: A doménreláció mint a lexikai kohézió eszköze. In: Károly K., Fóris Á. (szerk.) A forditás titkos ösvényein: Doktori kutatások Klaudy Kinga tiszteletére II. Budapest: ELTE Eötvös Kiadó. 27-44.

Halliday, M.A.K., Hasan, R. 1976. Cohesion in English. London: Longman.

Hasan, R. 1984. Cohenernce and cohesive harmony. In: Flood, J. (ed.) Understanding reading comprehension. Delaware: International Reading Association. 181-219.

Horváth P. I. 2011. A szakfordítások lektorálása. Elmélet és gyakorlat. Budapest: Tinta Könyvkiadó.

Károly K. 2007. Szövegtan és forditás. Budapest: Akadémiai Kiadó.

Károly K. 2010. Az ismétlésről a fordítási univerzálék tükrében. Magyar nyelv 106. évf. 3. sz. 322-338.

Károly K. 2011. Szöveg, koherencia, kohézió. Szövegtipológiai és retorikai tanulmányok. Budapest: Tinta Könyvkiadó.

Károly K. 2012. A referenciális kohézió a fordítási univerzálék tükrében (referenciális eltolódások a magyar-angol sajtófordításban). Magyar Nyelvőr 136. évf. 3. sz. 304-325.

Károly K., Ábrányi H., Kovalik Deák Sz., Laszkács Á., Mészáros A. É., Seresi M. 2012. Szövegkohézió és sajtófordítás: kohéziós eltolódások a hírszövegek magyar-angol fordításában. Forditástudomány 14 évf. 2. sz. 30-67.

Károly K. 2017. Logical relations in translation: the case of Hungarian-English news translation. Perspectives-Studies in Translatology Vol 25. No 2. 273-293.

Kis B., Mohácsi-Gorove A. 2008. A forditó számitógépe. Budapest: Szak Kiadó Kft.

Klaudy K. 2007. Nyelv és forditás. Budapest: Tinta Könyvkiadó.

Klaudy K. 2012. Bevezetés a fordítás gyakorlatába. Budapest: Scholastica.

Robin E. 2014. Fordítási univerzálék a lektorált szövegekben. Doktori disszertáció. Kézirat. Budapest: ELTE.

Tolcsvai Nagy G. 2001. A magyar nyelv szövegtana. Budapest: Nemzeti Tankönyvkiadó.

Sárosi-Márdirosz K. 2014. Problems Related to the Translation of Political Texts. Acta Universitatis Sapientiae, Philologica Vol. 5. No. 2. 159-180. 